\title{
Form IV of Carbamazepine
}

\author{
MEIDONG LANG, JEFF W. KAMPF, ADAM J. MATZGER \\ Department of Chemistry and Department of Macromolecular Science and Engineering, The University of Michigan, \\ Ann Arbor, Michigan 48109-1055
}

Received 25 July 2001; revised 26 November 2001; accepted 4 December 2001

\begin{abstract}
Carbamazepine has been found to crystallize as a new polymorph that is stable at room temperature. We report the crystal structure of this $C$-centered monoclinic form (space group $C 2 / c$, cell parameters: $a=26.609, b=6.9269, c=13.957$, $\beta=109.702$ ), which consists of hydrogen bonded dimers with an anti-disposition. This represents the third modification of carbamazepine that has been crystallographically characterized, and the fourth for which cell parameters have been determined. Thus, it is designated as form IV of carbamazepine. Differences between the packing of the various polymorphs are discussed. ( 2002 Wiley-Liss, Inc. and the American Pharmaceutical Association J Pharm Sci 91:1186-1190, 2002
\end{abstract}

Keywords: carbamazepine; polymorphism; X-ray diffraction; crystal structure; hydrogen bond

\section{INTRODUCTION}

Carbamazepine is an important drug for the treatment of epilepsy and trigeminal neuralgia whose crystallization has been thoroughly documented in nearly 100 publications in the literature with three stable forms being extensively characterized. ${ }^{1-14}$ Furthermore, because its bioavailability has been demonstrated to depend on the polymorph administered, its polymorphism is of great practical importance. ${ }^{7}$ The most stable of the known polymorphs at room temperature is a monoclinic form (form III) in the space group $P 2_{1} /$ $c$ with lattice parameters $a=7.529, b=11.148$, $c=15.470, \beta=116.17 .^{2}$ The molecules pack as hydrogen bonded dimers through the carboxamide group with an anti (centrosymmetric) relationship. The trigonal form (form II) has also been analyzed by single crystal X-ray diffraction and crystallizes in the space group $R \overline{3}$ with $a=35.454, c=5.253 .{ }^{4}$ Although the molecules exist as dimers very similar to the monoclinic

Correspondence to: Adam J. Matzger (Telephone: 734-6156627; Fax: 734-615-8553; E-mail: matzger@umich.edu)

Journal of Pharmaceutical Sciences, Vol. 91, 1186-1190 (2002)

(C) 2002 Wiley-Liss, Inc. and the American Pharmaceutical Association form, the packing of these units around a threefold screw axis leads to a more open structure (density at room temperature is $1.235 \mathrm{~g} / \mathrm{cm}^{3}$ and $1.343 \mathrm{~g} / \mathrm{cm}^{3}$ for the trigonal and monoclinic ${ }^{1}$ forms, respectively). A triclinic polymorph (form I) has been characterized by powder X-ray diffraction. Indexing of the powder pattern is consistent with the following lattice parameters: $a=20.61, b=5.24, c=22.30, \alpha=89.4, \beta=84.5$, $\gamma=85.5 .^{3}$ Assuming eight molecules in the unit cell gives a calculated density at room temperature of $1.31 \mathrm{~g} / \mathrm{cm}^{3}$. The relationships among these three forms have been studied in detail, and it is observed that upon melting the monoclinic form converts to the triclinic. ${ }^{15}$

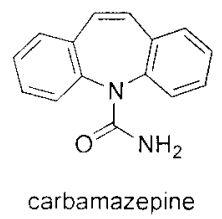

During our studies on the crystallization of carbamazepine we found that evaporation of $0.3 \mathrm{~mL}$ of a methanol solution $(1.5 \mathrm{~g} / 100 \mathrm{~mL}$, $20^{\circ} \mathrm{C}$ ) of the compound in the presence of $12 \mathrm{mg}$ of hydroxypropylcellulose $\left(M_{w}=60,000\right.$, Scientific Polymer Products, Inc., Ontario, NY) led to the 


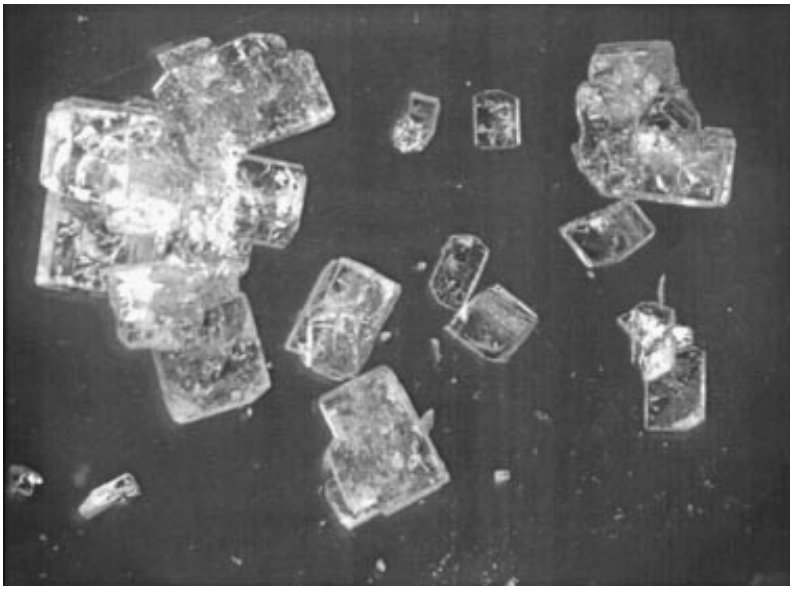

Figure 1. Observed morphology of the new carbamazepine polymorph obtained by seeding of a supersaturated solution.

formation of plate-like crystals in some trials in addition to the known triclinic (needles) and monoclinic (prisms) crystals. Production of this form by seeding supersaturated methanol solutions $\left(1.5 \mathrm{~g} / 10 \mathrm{~mL}, 20^{\circ} \mathrm{C}\right)$ yielded crystals as aggregates of plates occasionally contaminated with small amounts of triclinic needles (Figure 1). Elemental analysis agreed well with pure carbamazepine (Anal. calcd for $\mathrm{C}_{15} \mathrm{H}_{12} \mathrm{~N}_{2} \mathrm{O}: \mathrm{C}, 76.25 ; \mathrm{H}$, $5.12 ; \mathrm{N}, 11.86 \%$. Found $\mathrm{C}, 76.10 ; \mathrm{H}, 5.17 ; \mathrm{N}$, $11.81 \%$ ), and this data combined with the lack of mass loss in the TGA ruled out a solvate. To elucidate the arrangement of the molecules in this new polymorph we performed single crystal X-ray diffraction.

Collection of a full data set confirmed that, even in the case of this very well studied pharmaceutical, a new polymorph had been obtained. ${ }^{16}$ Carbamazepine was induced to crystallize in a $C$-centered monoclinic cell in the space group $C 2 /$ c. Cell parameters are $a=26.609, b=6.9269$, $c=13.957, \quad \beta=109.702$, and the density is $1.296 \mathrm{~g} / \mathrm{cm}^{3}\left(158 \mathrm{~K}, 1.268 \mathrm{~g} / \mathrm{cm}^{3}\right.$ using unit cell data acquired at $298 \mathrm{~K}$ ) making this polymorph easily distinguishable from the known monoclinic form, which crystallizes in a primitive cell. ${ }^{17}$ The bond lengths do not differ significantly from those determined for the primitive monoclinic or trigonal polymorphs (Figure 2, Tables 1 and 2). The azepine ring adopts a boat conformation similar to that found in the other structurally characterized forms, and the angles differ only slightly between the two monoclinic forms. Large differences among the torsional angles of the carboxamide group are not observed between the three forms,

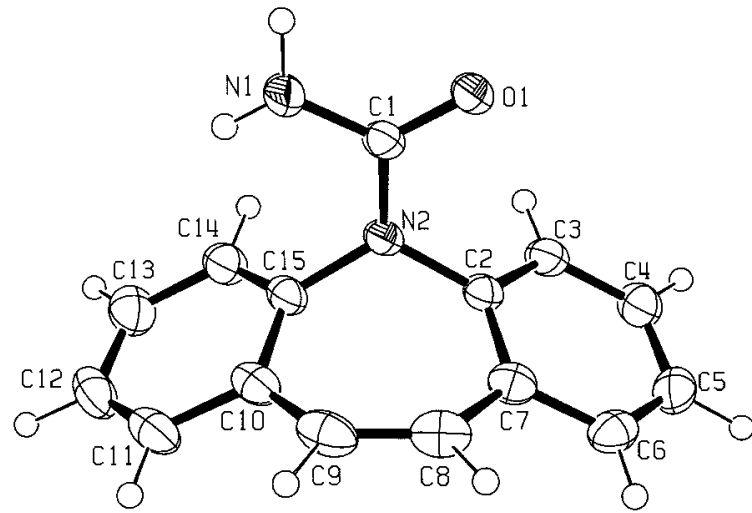

Figure 2. Thermal ellipsoid diagram of the $C$-centered monoclinic polymorph of carbamazepine.

perhaps a result of the dominance of dimer formation in dictating geometry.

The molecules pack as hydrogen-bonded dimers through the carboxamide group with an anti relationship (Figure 3). Although the conformation of the molecules within the dimers is similar among all three polymorphs, substantial differences exist between the packing of these units. The oxygen of the new polymorph is engaged in two short intermolecular hydrogen

Table 1. Atomic Coordinates $\left(\times 10^{4}\right)$ and Equivalent Isotropic Displacement Parameters $\left(\mathrm{A}^{2} \times 10^{3}\right)$ for $C$ Centered Monoclinic Carbamazepine

\begin{tabular}{lrrrr}
\hline & $\mathrm{x}$ & $\mathrm{y}$ & $\mathrm{z}$ & $\mathrm{U}(\mathrm{eq})^{a}$ \\
\hline $\mathrm{O}(1)$ & $722(1)$ & $-55(1)$ & $366(1)$ & $33(1)$ \\
$\mathrm{N}(1)$ & $145(1)$ & $1802(2)$ & $-841(1)$ & $42(1)$ \\
$\mathrm{N}(2)$ & $1059(1)$ & $2309(2)$ & $-372(1)$ & $29(1)$ \\
$\mathrm{C}(1)$ & $640(1)$ & $1278(2)$ & $-257(1)$ & $28(1)$ \\
$\mathrm{C}(2)$ & $1596(1)$ & $1662(2)$ & $140(1)$ & $28(1)$ \\
$\mathrm{C}(3)$ & $1841(1)$ & $2041(2)$ & $1168(1)$ & $33(1)$ \\
$\mathrm{C}(4)$ & $2349(1)$ & $1364(2)$ & $1674(1)$ & $38(1)$ \\
$\mathrm{C}(5)$ & $2615(1)$ & $297(2)$ & $1155(1)$ & $38(1)$ \\
$\mathrm{C}(6)$ & $2376(1)$ & $-48(2)$ & $129(1)$ & $36(1)$ \\
$\mathrm{C}(7)$ & $1862(1)$ & $632(2)$ & $-409(1)$ & $31(1)$ \\
$\mathrm{C}(8)$ & $1633(1)$ & $269(2)$ & $-1503(1)$ & $38(1)$ \\
$\mathrm{C}(9)$ & $1284(1)$ & $1351(2)$ & $-2218(1)$ & $39(1)$ \\
$\mathrm{C}(10)$ & $1054(1)$ & $3185(2)$ & $-2078(1)$ & $33(1)$ \\
$\mathrm{C}(11)$ & $917(1)$ & $4560(2)$ & $-2865(1)$ & $42(1)$ \\
$\mathrm{C}(12)$ & $731(1)$ & $6360(2)$ & $-2746(1)$ & $45(1)$ \\
$\mathrm{C}(13)$ & $674(1)$ & $6870(2)$ & $-1828(1)$ & $44(1)$ \\
$\mathrm{C}(14)$ & $800(1)$ & $5551(2)$ & $-1039(1)$ & $36(1)$ \\
$\mathrm{C}(15)$ & $976(1)$ & $3720(2)$ & $-1166(1)$ & $30(1)$ \\
\hline
\end{tabular}

${ }^{a} \mathrm{U}(\mathrm{eq})$ is defined as one-third of the trace of the orthogonalized Uij tensor. 
Table 2. Bond Lengths $[\AA]$ and Angles $\left[^{\circ}\right]$ for $C$-Centered Monoclinic Carbamazepine

\begin{tabular}{lclc}
\hline $\mathrm{O}(1)-\mathrm{C}(1)$ & $1.2362(14)$ & $\mathrm{C}(1)-\mathrm{N}(2)-\mathrm{C}(2)$ & $119.27(10)$ \\
$\mathrm{N}(1)-\mathrm{C}(1)$ & $1.3446(16)$ & $\mathrm{C}(1)-\mathrm{N}(2)-\mathrm{C}(15)$ & $121.52(10)$ \\
$\mathrm{N}(2)-\mathrm{C}(1)$ & $1.3772(15)$ & $\mathrm{C}(2)-\mathrm{N}(2)-\mathrm{C}(15)$ & $117.54(9)$ \\
$\mathrm{N}(2)-\mathrm{C}(2)$ & $1.4374(15)$ & $\mathrm{O}(1)-\mathrm{C}(1)-\mathrm{N}(1)$ & $122.16(11)$ \\
$\mathrm{N}(2)-\mathrm{C}(15)$ & $1.4382(15)$ & $\mathrm{O}(1)-\mathrm{C}(1)-\mathrm{N}(2)$ & $120.77(11)$ \\
$\mathrm{C}(2)-\mathrm{C}(3)$ & $1.3866(18)$ & $\mathrm{N}(1)-\mathrm{C}(1)-\mathrm{N}(2)$ & $117.07(11)$ \\
$\mathrm{C}(2)-\mathrm{C}(7)$ & $1.3999(17)$ & $\mathrm{C}(3)-\mathrm{C}(2)-\mathrm{C}(7)$ & $121.01(12)$ \\
$\mathrm{C}(3)-\mathrm{C}(4)$ & $1.3791(19)$ & $\mathrm{C}(3)-\mathrm{C}(2)-\mathrm{N}(2)$ & $119.73(11)$ \\
$\mathrm{C}(4)-\mathrm{C}(5)$ & $1.385(2)$ & $\mathrm{C}(7)-\mathrm{C}(2)-\mathrm{N}(2)$ & $119.26(11)$ \\
$\mathrm{C}(5)-\mathrm{C}(6)$ & $1.378(2)$ & $\mathrm{C}(4)-\mathrm{C}(3)-\mathrm{C}(2)$ & $120.21(13)$ \\
$\mathrm{C}(6)-\mathrm{C}(7)$ & $1.4010(19)$ & $\mathrm{C}(3)-\mathrm{C}(4)-\mathrm{C}(5)$ & $119.90(13)$ \\
$\mathrm{C}(7)-\mathrm{C}(8)$ & $1.4626(19)$ & $\mathrm{C}(6)-\mathrm{C}(5)-\mathrm{C}(4)$ & $119.90(13)$ \\
$\mathrm{C}(8)-\mathrm{C}(9)$ & $1.340(2)$ & $\mathrm{C}(5)-\mathrm{C}(6)-\mathrm{C}(7)$ & $121.55(13)$ \\
$\mathrm{C}(9)-\mathrm{C}(10)$ & $1.450(2)$ & $\mathrm{C}(2)-\mathrm{C}(7)-\mathrm{C}(6)$ & $117.40(12)$ \\
$\mathrm{C}(10)-\mathrm{C}(11)$ & $1.4066(19)$ & $\mathrm{C}(2)-\mathrm{C}(7)-\mathrm{C}(8)$ & $123.29(12)$ \\
$\mathrm{C}(10)-\mathrm{C}(15)$ & $1.4067(17)$ & $\mathrm{C}(6)-\mathrm{C}(7)-\mathrm{C}(8)$ & $119.30(12)$ \\
$\mathrm{C}(11)-\mathrm{C}(12)$ & $1.372(2)$ & $\mathrm{C}(9)-\mathrm{C}(8)-\mathrm{C}(7)$ & $128.42(14)$ \\
$\mathrm{C}(12)-\mathrm{C}(13)$ & $1.385(2)$ & $\mathrm{C}(8)-\mathrm{C}(9)-\mathrm{C}(10)$ & $127.40(13)$ \\
$\mathrm{C}(13)-\mathrm{C}(14)$ & $1.3826(19)$ & $\mathrm{C}(11)-\mathrm{C}(10)-\mathrm{C}(15)$ & $116.70(13)$ \\
$\mathrm{C}(14)-\mathrm{C}(15)$ & $1.384(2)$ & $\mathrm{C}(11)-\mathrm{C}(10)-\mathrm{C}(9)$ & $119.91(13)$ \\
& & $\mathrm{C}(15)-\mathrm{C}(10)-\mathrm{C}(9)$ & $123.35(12)$ \\
& & $\mathrm{C}(12)-\mathrm{C}(11)-\mathrm{C}(10)$ & $122.01(14)$ \\
& & $\mathrm{C}(11)-\mathrm{C}(12)-\mathrm{C}(13)$ & $120.03(14)$ \\
& & $\mathrm{C}(14)-\mathrm{C}(13)-\mathrm{C}(12)$ & $119.71(16)$ \\
& & $\mathrm{C}(13)-\mathrm{C}(14)-\mathrm{C}(15)$ & $120.33(14)$ \\
& & $\mathrm{C}(14)-\mathrm{C}(15)-\mathrm{C}(10)$ & $121.14(12)$ \\
& & $\mathrm{C}(14)-\mathrm{C}(15)-\mathrm{N}(2)$ & $119.64(12)$ \\
& & $\mathrm{C}(10)-\mathrm{C}(15)-\mathrm{N}(2)$ & $119.15(12)$ \\
\hline
\end{tabular}

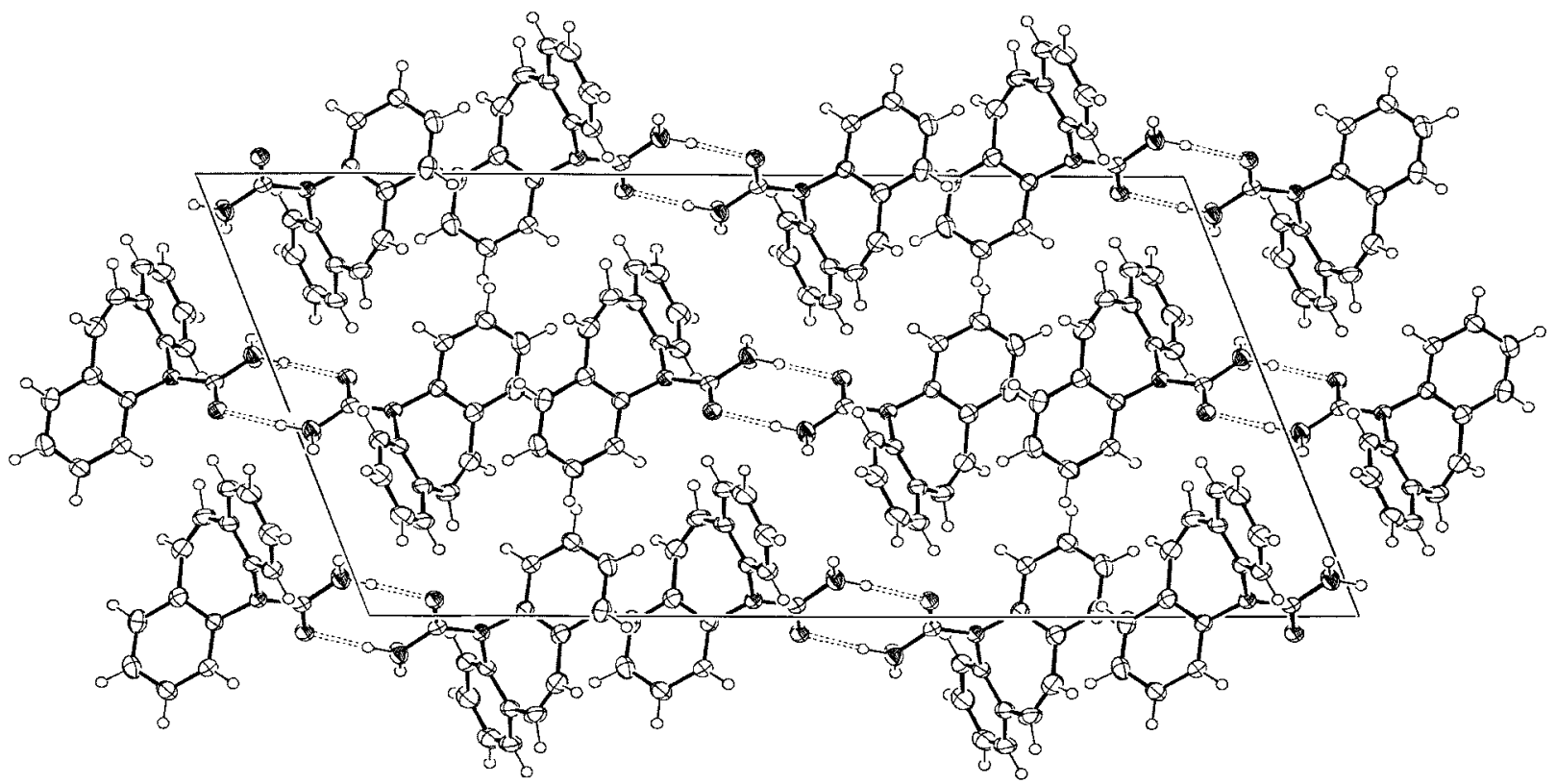

Figure 3. Molecular packing of the $C$-centered monoclinic polymorph of carbamazepine viewed along the $b$-axis revealing the presence of hydrogen-bonded dimers. 
bonds. The closest contact between the normalized (1.083 $\mathrm{\AA}, \mathrm{C}-\mathrm{H} ; 1.009 \AA, \mathrm{N}-\mathrm{H})$ position of the hydrogen on the urea syn to the oxygen of the carbonyl is $1.86 \AA$. This distance is similar to that in the primitive monoclinic polymorph $(1.92 \AA)$. However, in the new polymorph the carbonyl is only $2.28 \AA$ from a vinylic hydrogen in the sevenmembered ring while the corresponding value is $2.48 \AA$ in the primitive monoclinic form. This $\mathrm{CH} \cdots \mathrm{O}$ hydrogen bond links adjacent dimer pairs into infinite chains. The hydrogen on the urea anti to the oxygen of the carbonyl is $>2.7 \AA$ from an aromatic carbon, and is similar in both monoclinic forms. Differences between the $\pi-\pi$ interactions are also apparent among the three structures. The trigonal form lacks close facial aromatic stacking with shortest centroid-to-centroid distances of greater than $5 \AA$. By contrast, the primitive monoclinic polymorph contains both a long (centroid-centroid: $3.821 \AA$, centroidplane: $3.785 \AA$ ), nearly direct face-to-face stacking of inversion-related rings and a relatively shorter, but slightly slipped (centroid-centroid: $3.947 \AA$, centroid-plane: $3.542,3.686 \AA$ ), stacking between inequivalent benzene rings. The $C$-centered monoclinic form displays the closest stacking between the rings composed of carbons number 2 thru 7 (centroid-centroid: $3.809 \AA$, centroidplane: $3.445 \AA$ ).

Because this is the fourth well-characterized polymorph of carbamazepine, we designate it as form IV. ${ }^{18}$ We are currently studying the stability of this form at elevated temperature and humidity. Future studies will include the measurement of the dissolution rate and equilibrium solubility to determine if this may be a more efficacious form of this important drug.

\section{REFERENCES}

1. Himes VL, Mighell AD, De Camp WH. 1981. Structure of carbamazepine: $5 H$-dibenz $[b, f]$ azepine-5-carboxamide. Acta Crystallogr Sect B-Struct Sci 37:2242-2245.

2. Reboul JP, Cristau B, Soyfer JC, Astier JP. 1981. $5 H$-dibenz $[b, f]$ azépinecarboxamide-5 (carbamazepine). Acta Crystallogr Sect B-Struct Sci 37:18441848.

3. Ceolin R, Toscani S, Gardette MF, Agafonov VN, Dzyabchenko AV, Bachet B. 1997. X-ray characterization of the triclinic polymorph of carbamazepine. J Pharm Sci 86:1062-1065.

4. Lowes MMJ, Caira MR, Lötter AP, Van Der Watt JG. 1987. Physicochemical properties and X-ray structural studies of the trigonal polymorph of carbamazepine. J Pharm Sci 76:744-752.

5. Dugué J, Céolin R, Rouland JC, Lepage F. 1991. Polymorphism of carbamazepine: Solid-state studies on carbamazepine dihydrate. Pharmaceut Acta Helv 66:307-310.

6. Li YH, Han J, Zhang GGZ, Grant DJW, Suryanarayanan R. 2000. In situ dehydration of carbamazepine dihydrate: A novel technique to prepare amorphous anhydrous carbamazepine. Pharm Dev Technol 5:257-266.

7. Kobayashi Y, Ito S, Itai S, Yamamoto K. 2000. Physicochemical properties and bioavailability of carbamazepine polymorphs and dihydrate. Int $\mathrm{J}$ Pharm 193:137-146.

8. McMahon LE, Timmins P, Williams AC, York P. 1996. Characterization of dihydrates prepared from carbamazepine polymorphs. J Pharm Sci 85:10641069.

9. Reck G, Dietz G. 1986. The order-disorder structure of carbamazepine dihydrate: $5 \mathrm{H}$ - dibenz[b,f]azepine-5-carboxamide dihydrate, $\mathrm{C}_{15} \mathrm{H}_{12} \mathrm{~N}_{2} \mathrm{O} \cdot 2 \mathrm{H}_{2} \mathrm{O}$. Cryst Res Technol 21:1463-1468.

10. Reck G, Thiel W. 1991. Crystal-structures of the adducts carbamazepine-ammonium chloride and carbamazepine-ammonium bromide and their transformation in carbamazepine dihydrate. Pharmazie 46:509-512.

11. Rustichelli C, Gamberini G, Ferioli V, Gamberini MC, Ficarra R, Tommasini S. 2000. Solid-state study of polymorphic drugs: Carbamazepine. J Pharm Biomed Anal 23:41-54. Polymorph II in this article is not the same as the known trigonal form. However, no structural characterization is presented.

12. Suryanarayanan R. 1989. Determination of the relative amounts of anhydrous carbamazepine $\left(\mathrm{C}_{15} \mathrm{H}_{12} \mathrm{~N}_{2} \mathrm{O}\right)$ and carbamazepine dihydrate $\left(\mathrm{C}_{15} \mathrm{H}_{12} \mathrm{~N}_{2} \mathrm{O} \cdot 2 \mathrm{H}_{2} \mathrm{O}\right)$ in a mixture by powder X-ray diffractometry. Pharm Res 6:1017-1024.

13. Suryanarayanan R, Wiedmann TS. 1990. Quantitation of the relative amounts of anhydrous carbamazepine $\left(\mathrm{C}_{15} \mathrm{H}_{12} \mathrm{~N}_{2} \mathrm{O}\right)$ and carbamazepine dihydrate $\left(\mathrm{C}_{15} \mathrm{H}_{12} \mathrm{~N}_{2} \mathrm{O} \cdot 2 \mathrm{H}_{2} \mathrm{O}\right)$ in a mixture by solid-state nuclear magnetic resonance (NMR). Pharm Res 7:184-187.

14. Young WWL, Suryanarayanan R. 1991. Kinetics of transition of anhydrous carbamazepine to carbamazepine dihydrate in aqueous suspensions. J Pharm Sci 80:496-500.

15. Behme RJ, Brooke D. 1991. Heat of fusion measurement of a low melting polymorph of carbamazepine that undergoes multiple-phase changes during differential scanning calorimetry analysis. J Pharm Sci 80:986-990.

16. A crystal of dimensions $0.24 \times 0.18 \times 0.14 \mathrm{~mm}$ was cut from a larger crystal and mounted on a standard Bruker SMART CCD-based X-ray diffractometer 
equipped with a LT-2 low temperature device and normal focus Mo-target X-ray tube $(\lambda=0.71073 \AA)$ operated at $2000 \mathrm{~W}$ power $(50 \mathrm{kV}, 40 \mathrm{~mA})$. The Xray intensities were measured at $158(2) \mathrm{K}$; the detector was placed at a distance $4.939 \mathrm{~cm}$ from the crystal. A total of 2287 frames were collected with a scan width of $0.3^{\circ}$ in $\omega$ and $\phi$ with an exposure time of $30 \mathrm{~s} /$ frame. The frames were integrated with the Bruker SAINT software package with a narrow frame algorithm. The integration of the data yielded a total of 23,652 reflections to a maximum $2 \theta$ value of $52.78^{\circ}$ of which 2488 were independent and 1855 were greater than $2 \sigma(\mathrm{I})$. The final cell constants were based on the xyz centroids of 4250 reflections above $10 \sigma(\mathrm{I})$. Analysis of the data showed negligible decay during data collection; the data were processed with SADABS but not corrected for absorption. The structure was solved and refined with the Bruker SHELXTL (version 5.10) software package, using the space group $C 2 / \mathrm{c}$ with $\mathrm{Z}=8$ for the formula $\mathrm{C}_{15} \mathrm{H}_{12} \mathrm{~N}_{2} \mathrm{O}$. All nonhydrogen atoms were refined anisotropically with the hydrogen atoms located on a difference Fourier map and allowed to refine independently. Full matrix leastsquares refinement based on $F^{2}$ converged at $\mathrm{R} 1=0.0357$ and $\mathrm{wR} 2=0.0909$ [based on $\mathrm{I}>2 \sigma$ (I)], R1 $=0.0513$ and $w R 2=0.0956$ for all data.

17. An initial determination of cell constants was calculated from reflections harvested from three mutually orthogonal sets of 45 frames each. A reduced cell of $a=6.93, b=13.75, c=13.96$, $\alpha=70.96, \beta=90.00, \gamma=75.41$ was indexed and transformed to a standard $C$-centered monoclinic lattice. The reflection conditions $h k l: h+k=2 n+1$; $h 0 \mathrm{l}: h=2 n+1, \mathrm{l}=2 n+1$ define the space group choices as centrosymmetric $C 2 /$ c or noncentrosymmetric $C$ c. The solution and successful refinement in $C 2 /$ c confirms this choice as the proper assignment. Additional checks on any missing symmetry were performed by use of the ADDSYM subroutine of the PLATON program suite.

18. The reports of a fourth form of carbamazepine, obtained by cooling a solution of $2.00 \mathrm{~g}$ of carbamazepine in $100 \mathrm{~mL}$ of ethyl acetate to $-18^{\circ} \mathrm{C}$, seem not to have been generally accepted. Our attempts to repeat this method yielded crystals that by morphology and powder X-ray diffraction were identical with independently synthesized trigonal material, and were inconsistent with the unique powder diffraction pattern of $C$-centered monoclinic carbamazepine. Furthermore the three diffraction peaks that were assigned as diagnostic of the new polymorph were present in trigonal samples and were sensitive to sample orientation. For the original procedure see: Kala $\mathrm{H}$, Haack U, Pollandt P, Brezesinski G 1986. Zur polymorphie des carbamazepins. Acta Pharm Technol $32: 72-77$. 